International Journal of Engineering \& Technology, $7(2.6)(2018) 331-334$
International Journal of Engineering \& Technology
SPC
Website: www.sciencepubco.com/index.php/IJET
Research Paper

\title{
Portable Urban Agriculture Technology and Soil Nutrient Drive App That Support Farmers Profit
}

\author{
Ronny D Nasihien ${ }^{1}$, Iswachyu Dhaniarti ${ }^{2}$, Anton Muhibuddin ${ }^{3}$, Cholil Hasyim $^{4}$, M. Ikhsan Setiawan ${ }^{1 *}$, \\ Diah Ayu Restuti Wulandari ${ }^{1}$, Achfas Zacoeb ${ }^{5}$, Harimurti ${ }^{5}$, I Nyoman Sudapet ${ }^{6}$, \\ Darmawan Napitupulu', Ansari Saleh Ahmar $^{7}$, Mahrus Ali ${ }^{9}, \&$ Dani Harmanto ${ }^{10}$ \\ ${ }^{1}$ Department of Civil Engineering, Narotama University, Surabaya, Jawa Timur 60117, Indonesia \\ ${ }^{2}$ Department of Law, Narotama University, Surabaya, Jawa Timur 60117, Indonesia \\ ${ }^{3}$ Department of Agriculture, Brawijaya University, Malang, Jawa Timur 65145, Indonesia \\ ${ }^{4}$ Department of Management, Darul Ulum University, Jombang, Jawa Timur 61419, Indonesia \\ ${ }^{5}$ Department of Civil Engineering, Brawijaya University, Malang, Jawa Timur 65145, Indonesia \\ ${ }^{6}$ Department of Management, Narotama University, Surabaya, Jawa Timur 60117, Indonesia \\ ${ }^{7}$ Research Center for Quality System and Testing Technology, Indonesian Institute of Sciences, Jakarta, Indonesia \\ ${ }^{8}$ Department of Statistics, Universitas Negeri Makassar, Makassar, 90223, Indonesia \\ ${ }^{9}$ Departement of Agriculture, Merdeka University, Surabaya, Indonesia \\ ${ }^{10}$ University of Derby, School of Technology, Derby, United Kingdom \\ *Corresponding author E-mail: ikhsan.setiawan@narotama.ac.id
}

\begin{abstract}
A narrow land farmed urban Agriculture. It used for daily fresh vegetables and fruit for the housing community in urban areas. Portable Urban Agriculture Technology as a support facility to increase production of Urban Agriculture, the Greenhouse portable system could be built and transferred to a specific location is convenient, safe, fast, lightweight structural material (PVC $0.55 \mathrm{~mm}$ Tarpaulin) so that the Urban Agricultural Products closer to residential consumers in urban. The impact was the price was cheaper but quality. The objective was to plan, build and test prototype Water inflated tent activity as a facility to strengthen Greenhouse's strength, speed, effectiveness and comfort. Application method stages of the Cup or SDN on a former tin mining land, with Portable Urban Agriculture Technology support soil nutrient drive are as follows: first Reconstruction of the land in the form of land arrangement in accordance contours and irrigation channels that exist in the field is very important to support the success of the method SDN; second Management of top soil in the form of top soil enriched with organic material will support environmental compliance in the soil, especially for the growth and development of VAM hyphae and root system; third Soil Amendment to improve the physical and chemical properties of former mining land; fourth Activities vegetation of mined land with SDN method optimizes the achievement of the goals replanting of sustainable of native vegetation for erosion and runoff, repair and restoration of biodiversity, landscape aesthetics that will impact habitat improvement fauna, biodiversity, soil productivity and water quality. Tree plant species such as Acacia mangium, Acacia auriculiformis and Leucaena diversifolia microbes that have been infected with mycorrhizal fungi (VAM) will be very effective and support this effort. Vegetation activities with SDN method includes the following steps: first Seedling plants with VAM; second Preparation of arable land that supports the development of VAM in the soil; third Planting of the first cup with VAM; fourth Incubate 1 month; fifth Planting of the second cup with VAM; sixth 1 month incubation; and seventh The planting of the main crop.
\end{abstract}

Keywords: Urban Agriculture, Portable Technology, Greenhouse, Soil Nutrient Drive, and Vegetation

\section{Introduction}

FAO (Food and Agriculture Organization) describes urban Agriculture as the industries that produce, process, and market agricultural products, mainly meet the daily demand of consumers in urban areas, with intensive production methods, use and recycle resources and urban wastes to produce a variety of crops urban people's food needs. Council on Agriculture, Science and Technology (CAST) said Urban Farming covers aspects of environmental health, remediation, and recreation [1]-[2]. The Urban Agriculture into a beauty aspect of the city and the feasibility of the use of sustainable spatial. Urban agriculture is also done to increase revenues or activities produce food for family consumption, and in some places is done for the purpose of recreation and relaxation. Urban agriculture provides optimal results with facilities Greenhouse and Hydroponics technology. Greenhouse improve crop protection from rainfall, sunshine and microclimate, as well as optimizing plant maintenance, fertilization and micro irrigation, so as to increase the production of vegetables, fruits and flowers of quality irrespective of the season. Greenhouse easier with technology Air inflated Structure that can qualify strength, comfort in the room and speed in Greenhouse build-up. Membrane material can be resistant to weather up to more than 10 years, depending on the type of coating material[3]-[9] 

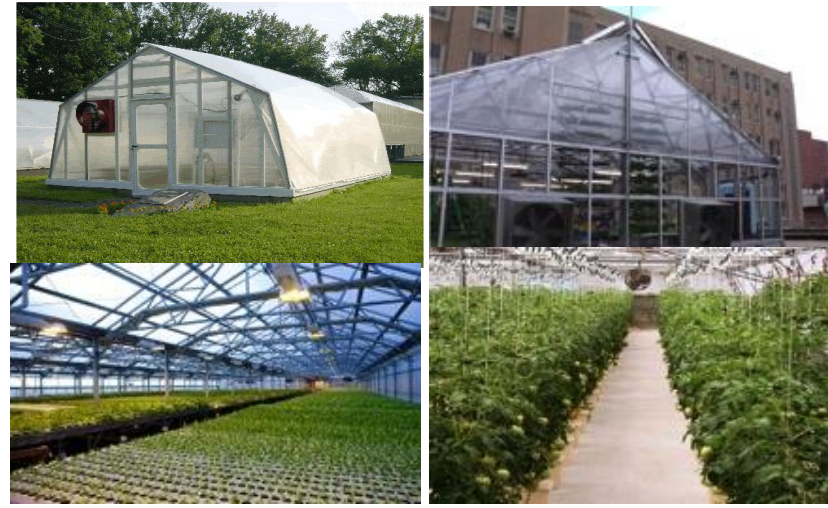

Fig 1. Greenhouse and supporting tools (greenestcity.ca)
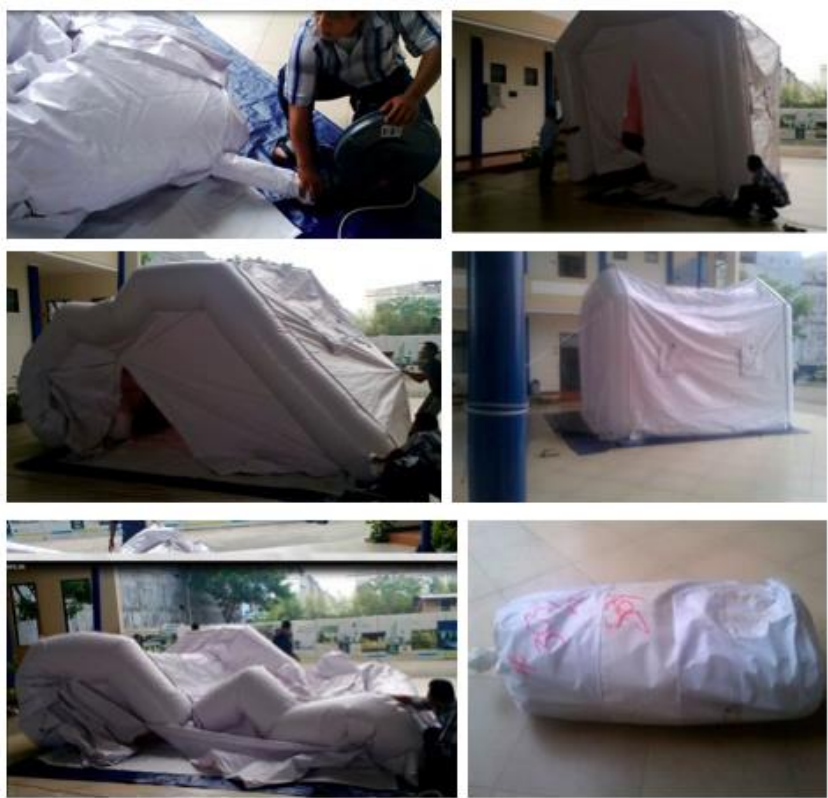

Fig. 2. Portable Urban Agriculture Technology

\section{Experimental Details}

Portable Urban Agriculture Technology could be used to support soil nutrient drive (SDN). Anton Muhibuddin discovered it in. The concept was a merger between the plate method of rooting in the soil formation of the network and two or three types of plants with different roots and vascular arbuscular mycorrhizae (VAM) specific symbioses with these plants. Tissue plant roots are formed at different depths due to differences in root distribution capabilities of each type of plant will form a cup shape in the soil (Figure 1). Cup rooting will also be supported by a network of hyphae of VAM that would connect between the dots on the roots of plants with a point on the ground deeper and point at the root of the other, so that the formation of a network of hyphae VAM will strengthen buffering capacity and power hold against nutrients, water, minerals, and other microbes that absorbed into the rhizosphere due VAM activity itself. Thus, the presence of VAM + host plants at SDN method will provide benefits in several ways[10][15]:

First, It absorbs nutrients more powerful and faster than in the soil as well as maintaining the presence of these nutrients through buffering capabilities and the ability to grasp the better. SDN very effective method is applied to the soil that has the ability to hold nutrients is weak, such as the former tin mining land, sandy soil in coastal areas, as well as other land with the ability of the caution exchange capacity (CEC) is low.

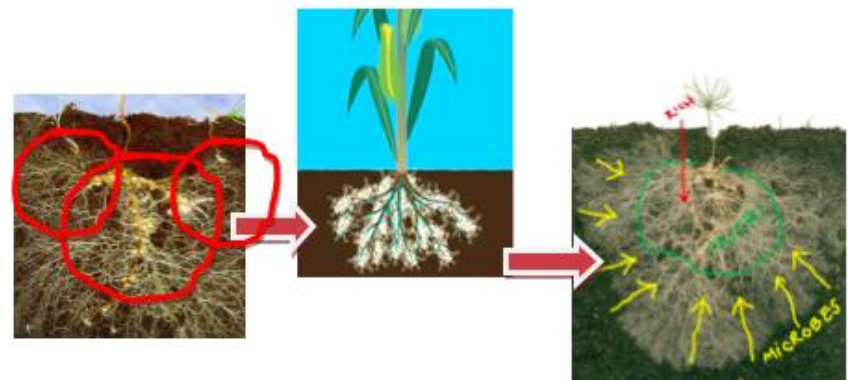

Fig 3. Types of different plants form roots of different distributions (the distribution of three different plants form a root-new; Infection VAM to expand its distribution and coverage of the plant roots; Activity roots + VAM increase nutrient uptake and storability of nutrients, water, minerals and microbes)

Second, increase the nature rhizosphere region. In addition to direct where VAM will be able to protect the roots against pathogens and pests ground because hyphae VAM that surrounds plant roots will protect directly from infectious pathogens, the distribution of hyphae in the whole territory of the rhizosphere will establish a new system which serves to absorb macro-micro soil and furthermore invited to come to the area of microbial soil rhizosphere. Invited soil microbes due to the presence of VAM + crop root system is comprised of approximately 98 percent beneficial microbes (decomposer, antagonist, insect pathogens, DLS.) And only about 2 percent that acts as a plant pathogen. Existence of beneficial microbes increases properties of the soil.

Third, improve the structure of the ground faster. Buildings in the soil formed from VAM hyphae distribution system, new microbial communities, the root-crop and nutrient bank will more quickly improve soil structure damaged due to agricultural activities either erroneous or as a result of mining activities. Land former tin mining which turned into predominantly sand $(70-95 \%$ and even $100 \%$ ), will be able to increase the quality is up to 30 times faster with the correct application of the system SDN.

Fourth, another advantage of applying the SDN method is specific microbes from particular regions of the particular soil depth. These specific microbes cannot be stimulated apart from the stimulation due to the SDN system where there is a combination of physical stimulation, chemical and biological simultaneously.

Fifth, SDN method is also very profitable for farmers because it provides economic benefits in the form of reduction of chemical inputs and non-chemical fertilizers and pesticides. Hyphae that form the network system will enhance the ability of roots to absorb soil nutrients to tens and even thousands of times. This capability reduces the need for crop nutrients from fertilizer and pesticide inputs.

\section{Results and Discussion}

Applications plate method in the field basically principled on a few things[16]-[23]:

First, precisely, three types of plants, forming cup. The selection of plants must hold the principle of conformity with the type of soil, providing economic benefits, conformity with the main crop, suitability in forming the cup in the soil. The formation of the cup in the soil is important because it serves as a nutrient bio keeper the main purpose in enriching and preserving wealth of nutrients and soil microbes;

Second, timeliness and way of planting crops or plants forming the main dish. Planting crops adapted to the forming bowls associated with the age of the plant due to the long and wide distribution of the plant roots. Cup-forming plants should be planted with appropriate spacing, proper planting time and planting the correct way, so that at the right time for the plants to be functioning properly to find nutrients and supported it; 
Third, the mycorrhizal symbiosis between plants and VAM as well as key in SDN method, because of an increase in accuracy and speed of uptake of soil nutrients, minerals, water, and an increased ability to hold strongly influenced by the presence of VAM;

Fourth, how the application of chemicals (fertilizers and pesticides) in the field must not damage the system that is being built in the soil ecosystem. When the hyphae tissue that has formed is damaged by the input of these materials, the system absorption of nutrients and the ability to hold nutrients are broken.

Application method stages of the Cup or SDN on a former tin mining land, with Portable Urban Agriculture Technology support soil nutrient drive are as follows:

First, reconstruction of the land in the form of land arrangement in accordance contours and irrigation channels that exist in the field is very important to support the success of the method SDN.

Second, management of top soil in the form of top soil enriched with organic material will support environmental compliance in the soil, especially for the growth and development of VAM hyphae and root system.

Third, soil Amendment to improve the physical and chemical properties of former mining land.

Fourth, activities vegetation of mined land with SDN method optimizes the achievement of the goals replanting of sustainable of native vegetation for erosion and runoff, repair and restoration of biodiversity, landscape aesthetics that will impact habitat improvement fauna, biodiversity, soil productivity and water quality. Tree plant species such as Acacia mangium, Acacia auriculiformis and Leucaena diversifolia microbes that have been infected with mycorrhizal fungi (VAM) will be very effective and support this effort.

Vegetation activities with SDN method includes the following steps:

(a) Seedling plants with VAM; (b) Preparation of arable land that supports the development of VAM in the soil; (c) Planting of the first cup (1) with VAM; (d) Incubate 1 month; (e) Planting of the second cup (2) with VAM; (f) 1 month incubation; (g) The planting of the main crop.

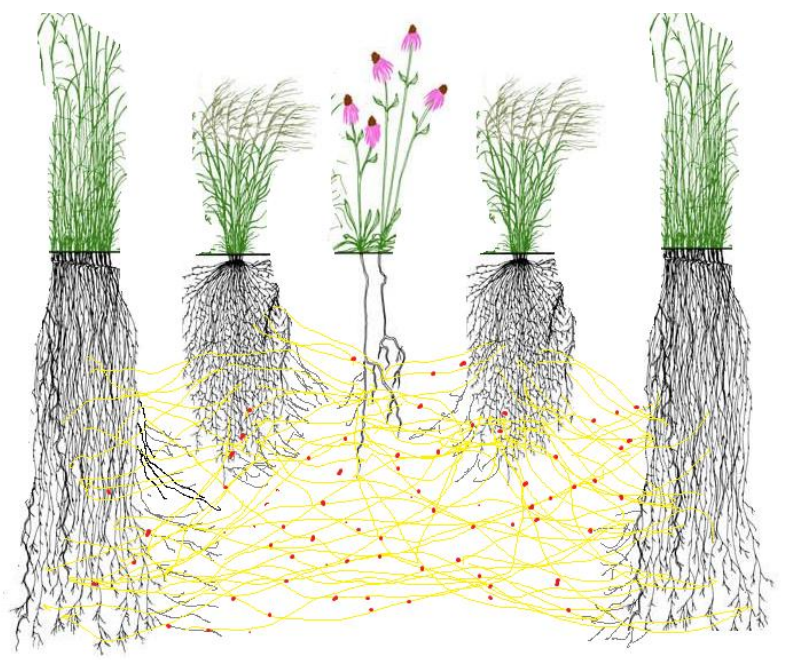

Fig 4. The network system hyphae of VAM + roots of plants in the ground formed at the 5 th month after planting the plants first cup

\section{Conclusions}

A narrow land farmed, urban Agriculture. It used for daily fresh vegetables and fruit for the housing community in urban areas. Portable Urban Agriculture Technology as a support facility to increase production of Urban Agriculture, the Greenhouse portable system could be built and transferred to a specific location is convenient, safe, fast, lightweight structural material (PVC $0.55 \mathrm{~mm}$ Tarpaulin) so that the Urban Agricultural Products closer to residential consumers in urban. The impact was the price was cheaper but quality. The objective was to plan, build and test prototype Water inflated tent activity as a facility to strengthen Greenhouse's strength, speed, effectiveness and comfort. The study used experiments, first, a test of strength and endurance of materials to the weather, second, test the most effective use of structural components, third, test the speed of Manufacture, transport, assembly, installation, demolition and fourth, test convenience. The tests were conducted at the Laboratory. It was proven to provide reliable and satisfying results include strong tensile test up to $218.3 \mathrm{~kg}$, the durability of the material to $>700 \mathrm{C}$, speed of installation and dismantling installations became more effective and efficient and comfort indoor maximum temperature of 350C. Portable Urban Agriculture Technology as a support facility to increase production of Portable Technology was also worth utilised as an Agricultural Tourism. Second, application method stages of the Cup or SDN on a former tin mining land, with Portable Urban Agriculture Technology support soil nutrient drive are as follows: (a) Reconstruction of the land in the form of land arrangement in accordance contours and irrigation channels that exist in the field is very important to support the success of the method SDN; (b) Management of top soil in the form of top soil enriched with organic material will support environmental compliance in the soil, especially for the growth and development of VAM hyphae and root system; (c) Soil Amendment to improve the physical and chemical properties of former mining land; (d) Activities vegetation of mined land with SDN method optimizes the achievement of the goals replanting of sustainable of native vegetation for erosion and runoff, repair and restoration of biodiversity, landscape aesthetics that will impact habitat improvement fauna, biodiversity, soil productivity and water quality. Tree plant species such as Acacia mangium, Acacia auriculiformis and Leucaena diversifolia microbes that have been infected with mycorrhizal fungi (VAM) will be very effective and support this effort. Vegetation activities with SDN method includes the following steps: (a) Seedling plants with VAM; (b) Preparation of arable land that supports the development of VAM in the soil; (c) Planting of the first cup (1) with VAM; (d) Incubate 1 month; (e) Planting of the second cup (2) with VAM; (f) 1 month incubation; (g) The planting of the main crop.

\section{Acknowledgement}

This paper is a part of Indonesian Ministry of Research, Technology, and Higher Education's Research Grants, research team are Ronny D Nasihien, Iswachyu Dhaniarti, M. Ikhsan Setiawan, Diah Ayu Restuti Wulandari, Cholil Hasyim, I Nyoman Sudapet, Darmawan Napitupulu, and Ansari Ahmar Saleh, supported by Experts, Dr Anton Muhibuddin, Dr Achfas Zacoeb, and Dr Harimurti, from Brawijaya University, Malang, Indonesia

\section{References}

[1] Teja, P. S. S., Vineel, M., Manisha, G., \& Satyanarayana, S. (2017). Automated irrigation system using sensors and node micro controller unit. International Journal of Engineering \& Technology, 7(1.1), 240-242.

[2] Singh, N., \& Gupta, N. (2017). Bayesian network for decisionsupport on pest management of tomato fruit borer, $\mathrm{H}$. armigera. International Journal of Engineering \& Technology, 6(4), 168170

[3] S. F. Rahmana, S. Nurhatika, and A. Muhibuddin, "Uji Potensi Fermentasi Etanol Beberapa Yeast yang Diisolasi dari Daerah Malang, Jawa Timur dengan Metode SDN (Soil Drive Nutrient)," J. Sains dan Seni ITS, vol. 5, no. 2, 2016.

[4] M. A. Syibli, A. Muhibuddin, and S. Djauhari, "Arbuscular Mycorrhiza Fungi as an Indicator of Soil Fertility," Agrivita, vol. 
35, no. 1, p. 44, 2013.

[5] D. P. Ningrum, A. Muhibuddin, and T. Sumarni, "Aplikasi Cendawan Mikoriza Arbuskular (CMA) Dan Bokashi Dalam Meminimalisir Pemberian Pupuk Anorganik Pada Produksi Benih Tanaman Jagung Ketan (Zea mays ceratina)," J. Produksi Tanam., vol. 1, no. 5, 2013.

[6] D. Y. R. Sari, T. B. Saputro, and A. Muhibuddin, "Uji Potensi Fermentasi Etanol Yeast Tanah yang Diisolasi dari Metode Budidaya SDN di Daerah Batu, Jawa Timur," J. Sains dan Seni ITS, vol. 5, no. 2, 2016.

[7] A. Muhibuddin, I. R. Sastrahidayat, S. M Mimbar, and S. Syekhfani, "Model Matematik Populasi Vesicular Arbuscular Mycorrhizae (Vam) Pada Pergiliran Tanaman Jagung Dan Kedelai Di Jatikerto, Malang,” Agrivita, vol. 29, no. 2, 2008.

[8] A. Muhibuddin and I. R. Sastrahidayat, "Soil Drive Nutrients Creation through Alternate Host System Propagation of VAM to Support Selective Exploration of Microbial Fermentation," Univ. Brawijaya. Malang, 2015.

[9] I. Rochjatun, S. Djauhari, N. Saleh, and A. Muhibuddin "Control of damping off disease caused by Sclerotium rolfsii Sacc. using actinomycetes and VAM fungi on soybean in the dry land based on microorganism diversity of rhizosphere zone," Agrivita, vol. 33, no. 1, p. 40, 2011.

[10] W. Astiko, I. R. Sastrahidayat, S. Djauhari, and A. Muhibuddin, "The role of indigenous mycorrhiza in combination with cattle manure in improving maize yield (Zea mays L) on sandy loam of northern Lombok, eastern of Indonesia," J. TANAH Trop. (Journal Trop. Soils), vol. 18, no. 1, pp. 53-58, 2013.

[11] N. K. M. D. Cahyani, S. Nurhatika, and A. Muhibuddin, "Eksplorasi mikoriza vesikular arbuskular (MVA) indigenous pada tanah Aluvial di Kabupaten Pamekasan Madura," J. Sains dan Seni ITS, vol. 3, no. 1, pp. E22-E25, 2014.

[12] S. Nurhalimah, S. Nurhatika, and A. Muhibuddin, "Eksplorasi Mikoriza Vesikular Arbuskular (MVA) Indigenous pada Tanah Regosol di Pamekasan, Madura," J. Sains dan Seni ITS, vol. 3 , no. 1, pp. E30-E34, 2014.

[13] D. Puspitasari, K. I. Purwani, and A. Muhibbudin, "Eksploras Vesicular Arbuscular Mycorrhiza (VAM) Indigenous pada Lahan Jagung di Desa Torjun, Sampang Madura," J. Sains dan Seni ITS, vol. 1, no. 1, pp. E19-E22, 2012.

[14] I. R. Sastrahidayat, "Rekayasa Pupuk Hayati Mikoriza Dalam Meningkatkan Produksi Pertanian," Univ. Brawijaya, 2011.

[15] M. I. Setiawan, S. Surjokusumo, D. M. Ma'soem, J. Johan, C. Hasyim, N. Kurniasih, A. Sukoco, I. Dhaniarti, J. Suyono, I. N. Sudapet, R. D. Nasihien, S. W. Mudjanarko, A. Wulandari, A. S. Ahmar, and M. B. N. Wajdi, "Business Centre Development Model of Airport Area in Supporting Airport Sustainability in Indonesia," J. Phys. Conf. Ser., vol. 954, no. 1, p. 12024, 2018.

[16] A. S. Ahmar, N. Kurniasih, D. E. Irawan, D. U. Sutiksno, D. Napitupulu, M. I. Setiawan, J. Simarmata, R. Hidayat, Busro, D. Abdullah, R. Rahim and J. Abraham, 'Lecturers' Understanding on Indexing Databases of SINTA, DOAJ, Google Scholar, SCOPUS, and Web of Science: A Study of Indonesians," J. Phys. Conf. Ser., vol. 954, no. 1, p. 12026, 2018.

[17] T. D. Laksono, N. Kurniasih, C. Hasyim, M. I. Setiawan, and A. S. Ahmar, "The Impact of Airport Performance towards Construction and Infrastructure Expansion in Indonesia," J. Phys. Conf. Ser., vol. 954, no. 1, p. 12015, 2018.

[18] D. Napitupulu, R. Rahim, D. Abdullah, M. I. Setiawan, L. A. Abdillah, A. S. Ahmar, J. Simarmata, R. Hidayat, H. Nurdiyanto, and A. Pranolo, "Analysis of Student Satisfaction Toward Quality of Service Facility," J. Phys. Conf. Ser., vol. 954, no. 1, p. 12019, 2018.

[19] Y. Hanun, M. I. Setiawan, N. Kurniasih, C. Hasyim, and A. S. Ahmar, "Airport Performance and Construction Enlargement Activities," J. Phys. Conf. Ser., vol. 954, no. 1, p. 12016, 2018.

[20] Ratnadewi, R. P. Adhie, Y. Hutama, A. S. Ahmar, and M. I. Setiawan, "Implementation Cryptography Data Encryption Standard (DES) and Triple Data Encryption Standard (3DES) Method in Communication System Based Near Field Communication (NFC)," J. Phys. Conf. Ser., vol. 954, no. 1, p. 12009, 2018.

[21] N. Kurniasih, C. Hasyim, A. Wulandari, M. I. Setiawan, and A. S. Ahmar, "Comparative Case Studies on Indonesian Higher Education Rankings," J. Phys. Conf. Ser., vol. 954, no. 1, p. 12021, 2018.

[22] Sabib, M. I. Setiawan, N. Kurniasih, A. S. Ahmar, and C. Hasyim, "Pavement Technology and Airport Infrastructure Expansion Impact,” J. Phys. Conf. Ser., vol. 954, no. 1, p. 12017 , 2018.
[23] J. Suyono, A. Sukoco, M. I. Setiawan, Suhermin, and R. Rahim, "Impact of GDP Information Technology in Developing of Regional Central Business (Case 50 Airports IT City Development in Indonesia)," IOP Conf. Ser. J. Phys. Conf. Ser., vol. 930, p. 11002, 2017. 